\title{
Delhayelite and Mountainite Mineral Families: Crystal Chemical Relationship, Microporous Character and Genetic Features
}

\author{
Igor V. Pekov, Natalia V. Zubkova, Nikita V. Chukanov, Anna G. Turchkova, \\ Yaroslav E. Filinchuk, and Dmitry Yu. Pushcharovsky
}

Many minerals show the properties commonly named "zeolitic": ion exchange and leaching, sorption of gases and organic molecules, reversible hydration, etc. The most well-known examples are aluminosilicate zeolites, clay minerals and pyrochlores. Besides them, several other large groups of minerals are now in focus of research as potential microporous materials or their prototypes. First, there are $\mathrm{Ti}-, \mathrm{Zr}-, \mathrm{Nb}$-silicates with heteropolyhedral frameworks. This paper is devoted to other minerals of this interest. There are two related families of natural silicates with structures based on $\mathrm{Si}, \mathrm{O}$ or $\mathrm{Al}, \mathrm{Si}, \mathrm{O}$ tetrahedral layers and columns of edge-shared $\mathrm{Ca}$-centered octahedra.

The delhayelite mineral family can be distinguished within the rhodesite meroplesiotype series (Ferraris and Gula 2005; Cadoni and Ferraris 2009) as its aluminosilicate branch that includes delhayelite, fivegite and hydrodelhayelite (Table 1). The idealized formula of delhayelite earlier presented as $\mathrm{K}_{7} \mathrm{Na}_{3} \mathrm{Ca}_{5}\left[\mathrm{AlSi}_{7} \mathrm{O}_{19}\right]_{2} \mathrm{~F}_{4} \mathrm{Cl}_{2}$ $(Z=1)$ (Cannillo et al. 1969) was recently refined: $\mathrm{K}_{4} \mathrm{Na}_{2} \mathrm{Ca}_{2}\left[\mathrm{AlSi}_{7} \mathrm{O}_{19}\right] \mathrm{F}_{2} \mathrm{Cl}(Z=2)$ (Pekov et al. 2009). Its crystal structure is based upon the double-layer tetrahedral blocks $\left[(\mathrm{Al}, \mathrm{Si})_{4} \mathrm{Si}_{12} \mathrm{O}_{38}\right]$ linked by the columns of Ca octahedra (Fig. 1a). Zeolite-like channels inside the tetrahedral blocks host $\mathrm{K}^{+}$and $\mathrm{Cl}^{-}$ions whereas the channels in the interlayer space, between Ca columns, host $\mathrm{Na}^{+}$and $\mathrm{F}^{-}$(Cannillo et al. 1969; Pekov et al. 2009). Fivegite, $\mathrm{K}_{4} \mathrm{Ca}_{2}\left[\mathrm{AlSi}_{7} \mathrm{O}_{17}\left(\mathrm{O}_{2-x} \mathrm{OH}_{x}\right)\right]\left[\left(\mathrm{H}_{2} \mathrm{O}\right)_{2-x} \mathrm{OH}_{x}\right] \mathrm{Cl}(x=0-2)$ (Pekov et al. 2010a), and hydrodelhayelite, $\mathrm{KCa}_{2}\left[\mathrm{AlSi}_{7} \mathrm{O}_{17}(\mathrm{OH})_{2}\right] \cdot(6-x) \mathrm{H}_{2} \mathrm{O}$ (Pekov et al. 2009; Ragimov et al. 1980), have the same Ca,Al,Si,O structure motif (rigid 3D part of the structure, $\mathrm{Ca}_{2}\left[\mathrm{AlSi}_{7} \mathrm{O}_{17} \varnothing_{2}\right]$, slightly distorted as compared with delhayelite, with protonated "pendent" vertices $\emptyset$ of Si tetrahedra) but different contents of the channels (Cannillo et al. 1969; Pekov et al. 2009) (Fig. 2). We consider this Ca,Al,Si,O motif as

I.V. Pekov $(\bowtie) \bullet$ N.V. Zubkova • A.G. Turchkova • D.Y. Pushcharovsky

Faculty of Geology, Moscow State University, Moscow, Russia

e-mail: igorpekov@mail.ru

N.V. Chukanov

Institute of Problems of Chemical Physics RAS, Chernogolovka, Russia

Y.E. Filinchuk

Swiss-Norwegian Beam Lines at ESRF, BP-220, 38043 Grenoble, France 
Table 1 Comparative data for minerals of the delhayelite family

\begin{tabular}{|c|c|c|c|}
\hline Mineral formula & $\begin{array}{l}\text { Delhayelite } \\
\mathrm{K}_{4} \mathrm{Na}_{2} \mathrm{Ca}_{2}\left[\mathrm{AlSi}_{7} \mathrm{O}_{19}\right] \\
\mathrm{F}_{2} \mathrm{Cl}\end{array}$ & $\begin{array}{l}\text { Fivegite } \\
\mathrm{K}_{4} \mathrm{Ca}_{2}\left[\mathrm{AlSi}_{7} \mathrm{O}_{17}\left(\mathrm{O}_{2-x}\right.\right. \\
\left.\left.\mathrm{OH}_{x}\right)\right]\left[\left(\mathrm{H}_{2} \mathrm{O}\right)_{2-x} \mathrm{OH}_{x}\right] \mathrm{Cl}\end{array}$ & $\begin{array}{l}\text { Hydrodelhayelite }^{\mathrm{a}} \\
\mathrm{KCa}_{2}\left[\mathrm{AlSi}_{7} \mathrm{O}_{17}(\mathrm{OH})_{2}\right] \\
\left(\mathrm{H}_{2} \mathrm{O}\right)_{6-x}\end{array}$ \\
\hline $\begin{array}{l}\text { Crystal system } \\
\text { space group }\end{array}$ & Orthorhombic Pmmn & Orthorhombic $P m 2_{1} n$ & Orthorhombic $P m 2_{1} n$ \\
\hline$a, \AA$ & 24.58 & 24.34 & 23.85 \\
\hline$b, \AA$ & 7.06 & 7.04 & 7.07 \\
\hline$c, \AA$ & 6.58 & 6.54 & 6.65 \\
\hline$V, \AA^{3}$ & 1,142 & 1,120 & 1,121 \\
\hline Z & 2 & 2 & 2 \\
\hline References & $\begin{array}{r}\text { (Cannillo et al. 1969; } \\
\text { Pekov et al. 2009) }\end{array}$ & (Pekov et al. 2010a) & $\begin{array}{l}\text { (Pekov et al. 2009; } \\
\quad \text { Ragimov et al. 1980) }\end{array}$ \\
\hline
\end{tabular}

${ }^{a}$ Hydrodelhayelite unit cell is given in the setting with tetrahedral layers perpendicular to the $a$ axis (with corresponding space group), like other minerals in this table

a

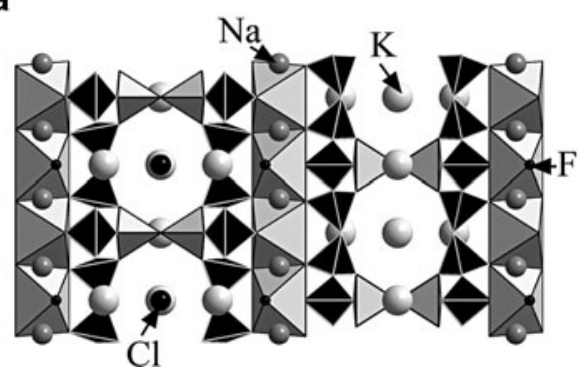

b

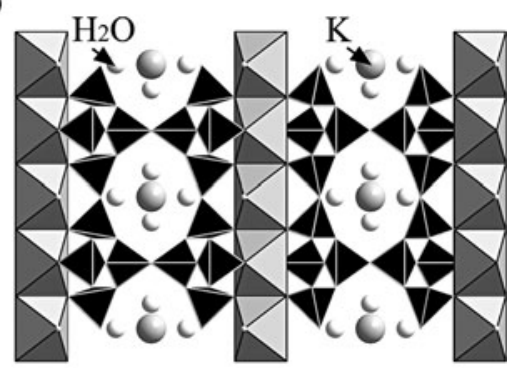

Fig. 1 Crystal structures of delhayelite (a): drawn based on the data from Pekov et al. (2009) and rhodesite (b): drawn based on the data from Hesse et al. (1992)): ab projections. Ca octahedral columns and the tetrahedral motifs are shown in polyhedra; Si tetrahedra are black, (Al,Si) tetrahedra in delhayelite are gray

a heteropolyhedral quasi-framework. If we do not take into account Ca octahedra then delhayelite-family members could be presented as phyllosilicates. However it seems more correct, from both physical and chemical viewpoints, to include $\mathrm{Ca}$ octahedral columns to the main building unit of these minerals.

The $\mathrm{Ca}, \mathrm{Al}, \mathrm{Si}, \mathrm{O}$ quasi-framework remains stable in natural transformation series delhayelite $\rightarrow$ fivegite $\rightarrow$ hydrodelhayelite (Pekov et al. 2010a) and in products of our experiments with delhayelite for ion leaching, cation exchange and hydration in aqueous systems (Turchkova et al. 2011). Thus the delhayelite family is a new, specific family of natural microporous aluminosilicates with zeolitic properties that is, in fact, intermediate between phyllo - and tecto-aluminosilicates. Its representatives delhayelite and fivegite differ from other microporous minerals by the presence of mobile halogen anions in the same channels as alkali cations. These ions are ordered in accordance with widths of the channels (Figs. 1 and 2). The hydrothermal alteration of delhayelite occurs step-by-step and shows different mobility of ions located in different structural sites: first leaching of $\mathrm{F}^{-}$and $\mathrm{Na}^{+}$from the interlayer space occurs and 

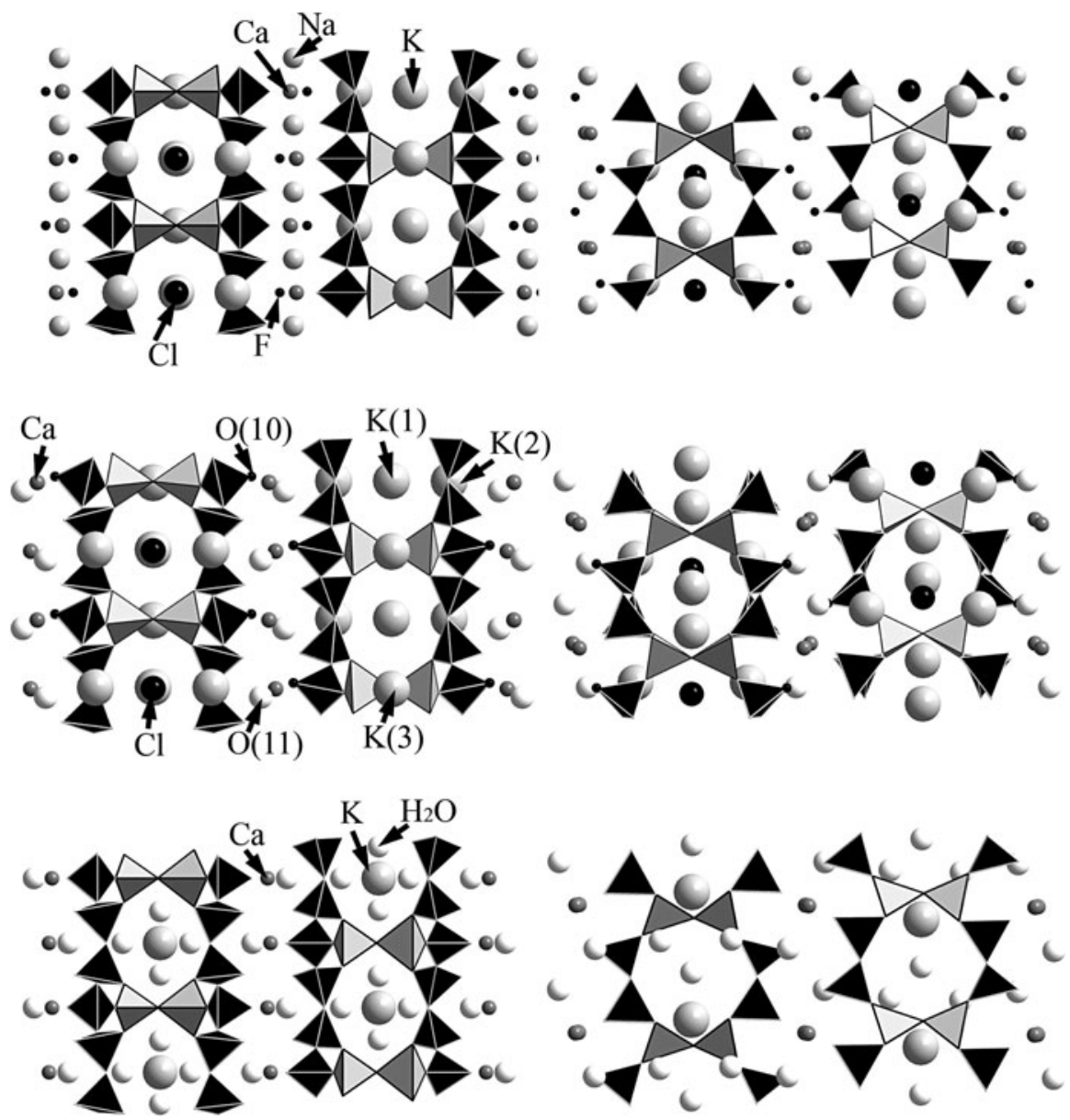

Fig. 2 Crystal structures (from top to bottom) of delhayelite, fivegite and hydrodelhayelite. $\mathrm{Si}$ tetrahedra are black, $(\mathrm{Al}, \mathrm{Si})$ tetrahedra are gray. Left column $-a b$ projections, right column ac projections, in the unified setting (see Table 1)

further $\mathrm{Cl}^{-}$and $\mathrm{K}^{+}$leave their sites within the tetrahedral block. These processes can be presented as following reactions:

(1) Delhayelite $\mathrm{K}_{4} \mathrm{Na}_{2} \mathrm{Ca}_{2}\left[\mathrm{AlSi}_{7} \mathrm{O}_{19}\right] \mathrm{F}_{2} \mathrm{Cl}+2 \mathrm{H}_{2} \mathrm{O} \rightarrow$ fivegite $\mathrm{K}_{4} \mathrm{Ca}_{2}\left[\mathrm{AlSi}_{7} \mathrm{O}_{17}\right.$ $\left.\left(\mathrm{O}_{2-x} \mathrm{OH}_{x}\right)\right]\left[\left(\mathrm{H}_{2} \mathrm{O}\right)_{2-x} \mathrm{OH}_{x}\right] \mathrm{Cl}+2 \mathrm{Na}^{+}+2 \mathrm{~F}^{-}$

(2) Fivegite $+(5-x) \mathrm{H}_{2} \mathrm{O} \rightarrow$ hydrodelhayelite $\mathrm{KCa}_{2}\left[\mathrm{AlSi}_{7} \mathrm{O}_{17}(\mathrm{OH})_{2}\right]\left(\mathrm{H}_{2} \mathrm{O}\right)_{6-x}+3$ $\mathrm{K}^{+}+\mathrm{Cl}^{-}$.

Delhayelite, fivegite and hydrodelhayelite are individual, well-stoichiometric minerals and transformations from one to other have discrete character: boarders between the initial and replacing phases in this evolution series are sharp (Pekov et al. 2010a). 
Table 2 Comparative data for minerals of the mountainite family

\begin{tabular}{|c|c|c|c|}
\hline Mineral formula & $\begin{array}{l}\text { Mountainite } \\
\mathrm{KNa}_{2} \mathrm{Ca}_{2}\left[\mathrm{Si}_{8} \mathrm{O}_{19}(\mathrm{OH})\right] \cdot 6 \mathrm{H}_{2} \mathrm{O}\end{array}$ & $\begin{array}{l}\text { Shlykovite } \mathrm{KCa} \\
{\left[\mathrm{Si}_{4} \mathrm{O}_{9}(\mathrm{OH})\right] \cdot 3 \mathrm{H}_{2} \mathrm{O}}\end{array}$ & $\begin{array}{l}\text { Cryptophyllite } \mathrm{K}_{2} \mathrm{Ca} \\
{\left[\mathrm{Si}_{4} \mathrm{O}_{10}\right] \cdot 5 \mathrm{H}_{2} \mathrm{O}}\end{array}$ \\
\hline $\begin{array}{l}\text { Crystal system } \\
\text { space group }\end{array}$ & Monoclinic $P 2 / c$ & Monoclinic $P 2_{1} / c$ & Monoclinic $P 2_{1} / n$ \\
\hline$\overline{a, \AA}$ & 13.70 & 6.49 & 6.49 \\
\hline$b, \AA$ & 6.58 & 7.00 & 6.99 \\
\hline$c, \AA$ & 13.75 & 26.71 & 32.09 \\
\hline$\beta,^{\circ}$ & 105.75 & 94.60 & 94.68 \\
\hline$V, \AA^{3}$ & 1,193 & 1,209 & 1,452 \\
\hline Z & 2 & 4 & 4 \\
\hline References & $\begin{array}{l}\text { (Gard et al. 1957; Zubkova } \\
\text { et al. 2009) }\end{array}$ & (Pekov et al. 2010b) & (Pekov et al. 2010b) \\
\hline
\end{tabular}

In our experiments on cation exchange (that is accompanied by significant hydration), leaching of contents of the interlayer space and channels shows the same sequence as simple hydration: first $\mathrm{F}$ and $\mathrm{Na}$, further $\mathrm{Cl}$ and $\mathrm{K}$. These facts indicate high selectivity of "zeolitic" characteristics of delhayelite-family minerals that makes them (and related synthetic compounds) promising as technologically usable microporous materials.

Rhodesite, $\mathrm{KCa}_{2}\left[\mathrm{Si}_{8} \mathrm{O}_{18}(\mathrm{OH})\right] \cdot(6-x) \mathrm{H}_{2} \mathrm{O}$, the structural analogue of hydrodelhayelite with $\mathrm{Si}$ instead of $\mathrm{Al}$ in corresponding tetrahedral sites (Pekov et al. 2009; Hesse et al. 1992) (Fig. 1b), can be considered as a "bridge" between aluminosilicates of the delhayelite family and crystal chemically related Al-free silicates of the mountainite family of natural phyllosilicates recently defined in (Pekov et al. 2010b).

The mountainite family includes three minerals (Table 2) with unique, different one from others but related structures. The structure of mountainite, a mineral known since 1957 (Gard et al. 1957), was solved in 2008 and its crystallochemically correct formula was determined: $\mathrm{KNa}_{2} \mathrm{Ca}_{2}\left[\mathrm{Si}_{8} \mathrm{O}_{19}(\mathrm{OH})\right] \cdot 6 \mathrm{H}_{2} \mathrm{O}(\mathrm{Z}=2$ ) (Zubkova et al. 2009). Shlykovite, $\mathrm{K}_{2} \mathrm{Ca}_{2}\left[\mathrm{Si}_{8} \mathrm{O}_{18}(\mathrm{OH})_{2}\right] \cdot 6 \mathrm{H}_{2} \mathrm{O}$, and cryptophyllite, $\mathrm{K}_{4} \mathrm{Ca}_{2}\left[\mathrm{Si}_{8} \mathrm{O}_{20}\right]$. $10 \mathrm{H}_{2} \mathrm{O}$, are new minerals discovered in 2009 in the Khibiny alkaline complex, Kola Peninsula, Russia (Pekov et al. 2010b).

The main structural unit of all three minerals is TOT block consisting of two identical tetrahedral Si layers $(T)\left[\mathrm{Si}_{8} \mathrm{O}_{18}(\mathrm{O}, \mathrm{OH})_{2}\right]$ and an octahedral component $(O)$, formed by columns of edge-sharing $\mathrm{Ca}$ octahedra sandwiched between them (Fig. 3). Single $T$-layer in shlykovite and cryptophyllite is topologically the same as half of the double-layer block of rhodesite, $\left[\mathrm{Si}_{16} \mathrm{O}_{36}(\mathrm{OH})_{2}\right]$, or delhayelite, [( $\mathrm{Al}$, $\mathrm{Si})_{4} \mathrm{Si}_{12} \mathrm{O}_{38}$ ] (Fig. 4). $T$-layer in mountainite is very similar and differs from that of shlykovite and cryptophyllite only by the orientation of some Si tetrahedra that causes the difference in configuration of the $\mathrm{Ca}$ octahedral columns in these minerals. $\mathrm{K}^{+}$cations are located in channels within TOT blocks in all three minerals, like delhayelite-family members that also contain only the largest $\mathrm{K}^{+}$cations in channels within the tetrahedral block. 
a

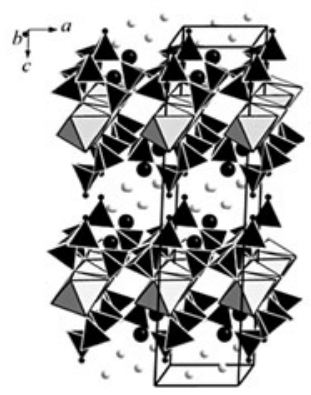

b

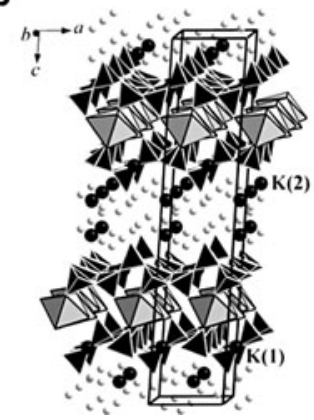

C

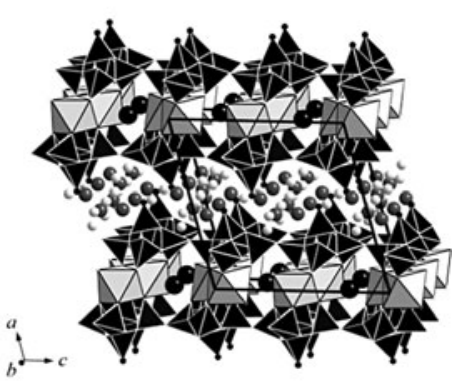

Fig. 3 Crystal structures of shlykovite (a), cryptophyllite (b), and mountainite (c), $\mathrm{SiO}_{4}$ tetrahedra are black, $\mathrm{Ca}$ octahedra are light grey. $\mathrm{K}$ cations are shown as large black circles, $\mathrm{O}$ atoms of $\mathrm{H}_{2} \mathrm{O}$ molecules - as small grey circles. Na atoms in mountainite are marked as large grey spheres. Positions of $\mathrm{OH}$-groups in shlykovite and $(\mathrm{O}, \mathrm{OH})$ in mountainite are shown as small black circles

a
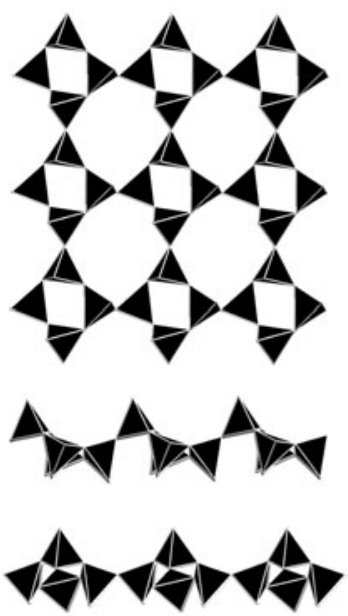

b
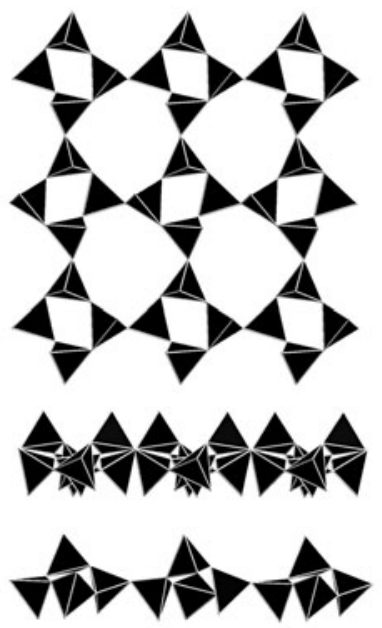

C
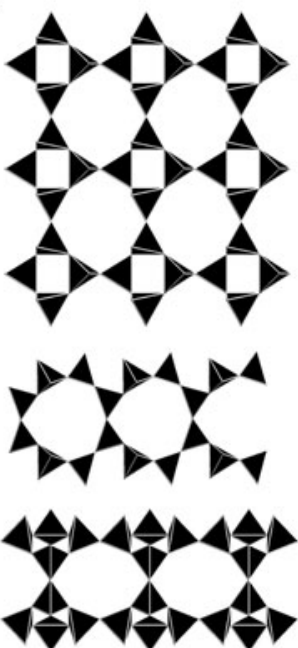

Fig. 4 Silicate layer formed by 4 - and 8-membered rings in the structures of shlykovite and cryptophyllite (a), mountainite (b), and rhodesite (c)

Unlike rhodesite mero-plesiotype series minerals with heteropolyhedral quasi-frameworks, members of the mountainite family are true phyllosilicates: TOT blocks are isolated from each other and only $\mathrm{H}_{2} \mathrm{O}$ molecules (shlykovite) or $\mathrm{H}_{2} \mathrm{O}$ molecules and alkali cations $\left(\mathrm{K}^{+}\right.$in cryptophyllite, $\mathrm{Na}^{+}$in mountainite) are located between them (Fig. 3). An important feature of the mountainite family is the variability of the distance between TOT blocks (that determines the basal parameter of unit cell) in accordance with interlayer contents: $\left(\mathrm{H}_{2} \mathrm{O}\right)_{4}$ in shlykovite $(c=26.7 \AA), \mathrm{K}_{2}\left(\mathrm{H}_{2} \mathrm{O}\right)_{8}$ in cryptophyllite $(c=32.1 \AA)$ or $\mathrm{Na}_{2}\left(\mathrm{H}_{2} \mathrm{O}\right)_{4}$ in mountainite $(2 a=27.5 \AA)$. 
This variability and significant hydration capacity indicate great potential of mountainite-family minerals as new microporous materials suitable to the exchange of large cations and, probably, their immobilization after heating for $\mathrm{H}_{2} \mathrm{O}$ removal and structure contraction.

Minerals of both the delhayelite and the mountainite families were only found in the alkaline formation. Common feature of all of them is species-defining role of $\mathrm{K}$ (Tables 1 and 2) and they occur in potassium-enriched rocks or their derivatives. Delhayelite, the only anhydrous mineral among six representatives of these families, is formed under high-temperature conditions in K-rich peralkaline rocks and related pegmatites. All other discussed minerals have hydrothermal origin. The Al-bearing species, fivegite and hydrodelhayelite, are known only as products of transformation of delhayelite with preservation of its stable $\mathrm{Ca}, \mathrm{Al}, \mathrm{Si}, \mathrm{O}$ heteropolyhedral quasiframework whereas Al-free minerals (mountainite family) crystallize directly from low-temperature hydrothermal solutions just as rhodesite. The minerals with single and double tetrahedral layers are formed under the same conditions, sometimes together. Intimate intergrowths of mountainite and rhodesite were found in hydrothermally altered kimberlitic rock at Bultfontein, South Africa (Gard et al. 1957). In one pegmatite body at Mt. Rasvumchorr in Khibiny, we have observed five of six minerals (except mountainite) of both discussed families. In the late-stage, low-temperature hydrothermal assemblage hydrodelhayelite, occurring as partial or complete pseudomorphs after fivegite (that partially or completely replaced delhayelite), is associated with shlykovite and cryptophyllite typically forming intimate intergrowths in cracks and cavities of this pegmatite.

Acknowledgements This work was supported by grants nos. 08-07-00077-a, 09-05-00143-a, and 09-05-12001-ofi_m by RFBR and grants of President of Russian Federation nos. MK-320.2010.5, NSh-4034.2010.5 and NSh-3848.2010.5.

\section{References}

Cadoni M, Ferraris G (2009) Two new members of the rhodesite mero-plesiotype series close to delhayelite and hydrodelhayelite: synthesis and crystal structure. Eur J Miner 21:485-493

Cannillo E, Rossi G, Ungaretti L (1969) The crystal structure of delhayelite. Rend Soc Ital Miner Pet 26:63-75

Ferraris G, Gula A (2005) Polysomatic aspects of microporous minerals - heterophyllosilicates, palysepioles and rhodesite-related structures. Rev Miner Geochem 57:69-104

Gard JA, Taylor HFW, Chalmers RA (1957) An investigation of two new minerals: rhodesite and mountainite. Miner Mag 31:611-623

Hesse KF, Liebau F, Merlino S (1992) Crystal structure of rhodesite, $\mathrm{HK}_{1-\mathrm{x}} \mathrm{Na}_{\mathrm{x}+2 \mathrm{y}} \mathrm{Ca}_{2-\mathrm{y}}$ $\left\{1 \mathrm{~B}, 3,2_{\infty}{ }^{2}\right\}\left[\mathrm{Si}_{8} \mathrm{O}_{19}\right] \bullet(6-\mathrm{z}) \mathrm{H}_{2} \mathrm{O}$, from three localities and its relation to other silicates with dreier double layers. Z Kristallogr 199:25-48

Pekov IV, Zubkova NV, Chukanov NV, Sharygin VV, Pushcharovsky DYu (2009) Crystal chemistry of delhayelite and hydrodelhayelite. Dokl Earth Sci 428(7):1216-1221

Pekov IV, Zubkova NV, Chukanov NV, Zadov AE, Pushcharovsky DYu (2010a) Fivegite, $\mathrm{K}_{4} \mathrm{Ca}_{2}\left[\mathrm{AlSi}_{7} \mathrm{O}_{17}\left(\mathrm{O}_{2-\mathrm{x}} \mathrm{OH}_{\mathrm{x}}\right)\right]\left[\left(\mathrm{H}_{2} \mathrm{O}\right)_{2-\mathrm{x}} \mathrm{OH}_{\mathrm{x}}\right] \mathrm{Cl}$, a new mineral from the Khibiny alkaline complex, Kola Peninsula, Russia. Zap RMO 139(4):47-63 (in Russian) 
Pekov IV, Zubkova NV, Filinchuk YaE, Chukanov NV, Zadov AE, Pushcharovsky DYu, Gobechiya ER (2010b) Shlykovite, $\mathrm{KCa}\left[\mathrm{Si}_{4} \mathrm{O}_{9}(\mathrm{OH})\right] \cdot 3 \mathrm{H}_{2} \mathrm{O}$, and cryptophyllite, $\mathrm{K}_{2} \mathrm{Ca}$ $\left[\mathrm{Si}_{4} \mathrm{O}_{10}\right] \cdot 5 \mathrm{H}_{2} \mathrm{O}$, two new mineral species from the Khibiny alkaline complex, Kola Peninsula, Russia. Zap RMO 139(1):37-50 (in Russian)

Ragimov KG, Chiragov MI, Mamedov KS, Dorfman MD (1980) Crystal structure of hydrodelhayelite, $\mathrm{KH}_{2} \mathrm{Ca}_{2}(\mathrm{Si}, \mathrm{Al})_{8} \mathrm{O}_{19} \cdot 6 \mathrm{H}_{2} \mathrm{O}$. Doklady AN Azerb SSR 36(12):49-51 (in Russian)

Turchkova AG, Pekov IV, Lykova IS, Chukanov NV, Yapaskurt VO (2011) Delhayelite: ion leaching and ion exchange. In: Krivovichev SV (ed) Minerals as advanced materials II, 221-228

Zubkova NV, Pekov IV, Pushcharovsky DYu, Chukanov NV (2009) The crystal structure and refined formula of mountainite, $\mathrm{KNa}_{2} \mathrm{Ca}_{2} \mathrm{Si}_{8} \mathrm{O}_{19}(\mathrm{OH}) \cdot 6 \mathrm{H}_{2} \mathrm{O}$. Z Kristallogr 224:389-396 